\title{
ELF4 Gene
}

National Cancer Institute

\section{Source}

National Cancer Institute. ELF4 Gene. NCI Thesaurus. Code C97470.

This gene plays a role in both DNA binding and transcriptional activation. 